\title{
Late Cenozoic sea level and the rise of modern rimmed atolls
}

\author{
Michael R. Toomey ${ }^{\mathrm{a}, \mathrm{b}, *}$, Andrew D. Ashton ${ }^{\mathrm{c}}$, Maureen E. Raymo ${ }^{\mathrm{d}}$, J. Taylor Perron ${ }^{\mathrm{e}}$ \\ ${ }^{a}$ Eastern Geology and Paleoclimate Science Center, United States Geological Survey, Mail Stop 926A, 12201 Sunrise Valley Drive, Reston, VA 20192, USA \\ b Jackson School of Geosciences, University of Texas at Austin, Austin, TX 78712, USA \\ c Department of Geology E' Geophysics, Woods Hole Oceanographic Institution, Mail Stop 22, 360 Woods Hole Rd., Woods Hole, MA 02543, USA \\ d Lamont-Doherty Earth Observatory, Columbia University, 61 Route 9W, Palisades, NY 10964, USA \\ e Department of Earth, Atmospheric, and Planetary Sciences, Massachusetts Institute of Technology, Cambridge, MA 02139, USA
}

\section{A R T I C L E I N F O}

\section{Article history:}

Received 9 October 2015

Received in revised form 3 March 2016

Accepted 18 March 2016

Available online 23 March 2016

\section{Keywords:}

Reef

Coral

Dissolution

Late Miocene

Oxygen isotope stack

\begin{abstract}
A B S T R A C T
Sea-level records from atolls, potentially spanning the Cenozoic, have been largely overlooked, in part because the processes that control atoll form (reef accretion, carbonate dissolution, sediment transport, vertical motion) are complex and, for many islands, unconstrained on million-year timescales. Here we combine existing observations of atoll morphology and corelog stratigraphy from Enewetak Atoll with a numerical model to (1) constrain the relative rates of subsidence, dissolution and sedimentation that have shaped modern Pacific atolls and (2) construct a record of sea level over the past 8.5 million years. Both the stratigraphy from Enewetak Atoll (constrained by a subsidence rate of $\sim 20 \mathrm{~m} / \mathrm{Myr}$ ) and our numerical modeling results suggest that low sea levels (50-125 m below present), and presumably bi-polar glaciations, occurred throughout much of the late Miocene, preceding the warmer climate of the Pliocene, when sea level was higher than present. Carbonate dissolution through the subsequent sea-level fall that accompanied the onset of large glacial cycles in the late Pliocene, along with rapid highstand constructional reef growth, likely drove development of the rimmed atoll morphology we see today.
\end{abstract}

Published by Elsevier B.V.

\section{Introduction}

The shapes of many modern atolls have been compared to a bucket of water, with a narrow coral rim at sea level encircling a deeper central lagoon (Ladd and Tracey, 1949; Purdy and Gischler, 2005). However, much controversy surrounds which geologic process (subsidence, Darwin, 1842; dissolution, MacNeil, 1954; or sea-level variability, Daly, 1910) led to the formation of these deep lagoons, or 'emptybuckets.' Following the drilling and recovery of basalt $\sim 1267 \mathrm{~m}$ below the rim of Enewetak Atoll (a.k.a, Eniwetok, Eniewetok), Marshall Islands in 1952 A.D. (Ladd and Schlanger, 1960), Darwin's theory of subsidence control, which proposes an evolution from fringing reef (Fig. 1a) to barrier reef (Fig. 1b) to empty-bucket atoll (Fig. 1c) as an ocean island ages and subsides, became widely accepted.

Although these and other drilling efforts (Buigues, 1985; Ladd et al., 1970) provide compelling evidence that atolls are built on ocean island foundations, drill-core logs and morphologic observations expose several problems with subsidence as the driver of "empty-bucket" atoll formation. For instance, lagoon sedimentation rates (typically $>1 \mathrm{~mm} / \mathrm{yr}$ during the Holocene $\approx 1000 \mathrm{~m} / \mathrm{Myr}$; Montaggioni, 2005)

\footnotetext{
* Corresponding author at: Eastern Geology and Paleoclimate Science Center, United States Geological Survey, Mail Stop 926A, 12201 Sunrise Valley Drive, Reston, VA 20192, USA.

E-mail address: mtoomey@usgs.gov (M.R. Toomey).
}

far outpace atoll subsidence rates ( 15-30 m/Myr; Section 3.1) and thus lagoons would rapidly be filled in the absence of depositional hiatuses due to subaerial exposure during sea-level lowstands (Purdy and Gischler, 2005) or sediment 'leaks' due to strong currents and incomplete closure of the rim (e.g., Betzler et al., 2015; Purdy and Gischler, 2005). Rapid infilling should produce 'full-bucket' atolls typified by shallow, sediment-filled lagoons (Fig. 1d, e) that are quite common throughout the equatorial Pacific. Further, initiation of modern atoll rims in the Marshall Islands (Lincoln and Schlanger, 1991), Maldives (Schlager and Purkis, 2013 and refs. therein) and French Polynesia (Buigues, 1985) during the late Miocene suggests that other environmental forcings, not local subsidence, drive changes in atoll morphology. Widespread evidence of surface dissolution of carbonate by rainwater (e.g., subaerial erosion) on uplifted atolls led MacNeil (1954) to suggest, alternatively, that deep atoll lagoons (Fig. 1c) formed through a combination of constructional reef growth along atoll rims during interglacial sea-level highstands coupled with enhanced dissolution of lagoonal sediments during glacial lowstands.

Perhaps the most striking evidence that carbonate dissolution (or lack thereof) has driven differential changes in atoll morphology is the geographic distribution of full-buckets, empty-buckets and submerged atolls/banks (rim still catching up to sea level) in the modern Pacific (Fig. 1e). Two submerged atoll/bank provinces are located within regions of high precipitation during the last glacial maximum (Western-Pacific Warm Pool and the South Pacific Convergence Zone; $\geq 10 \mathrm{~mm} /$ day; 

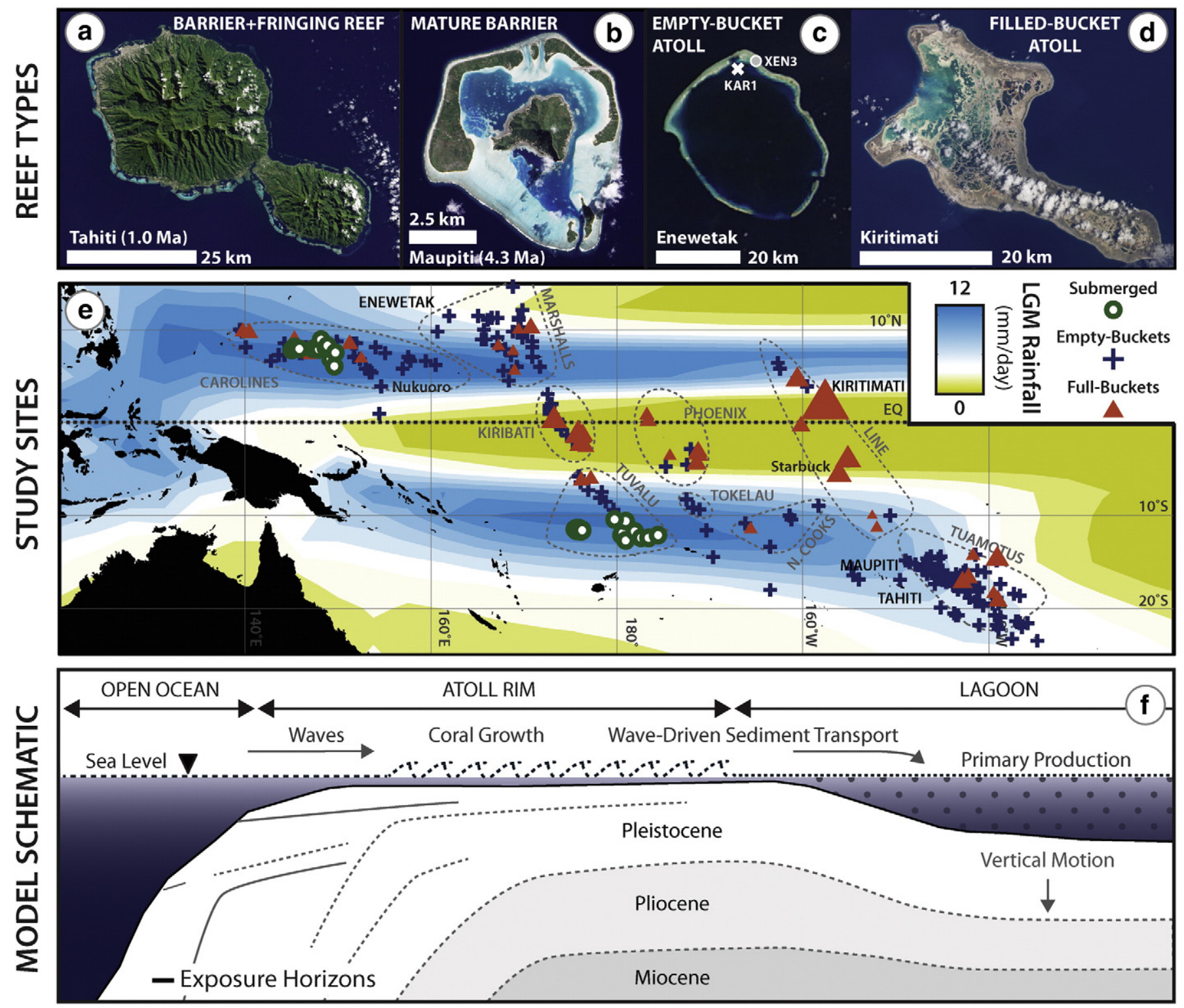

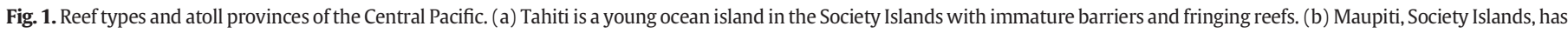

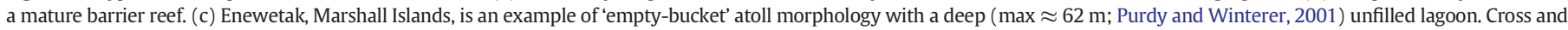

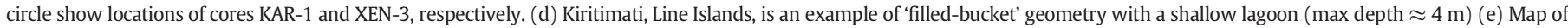

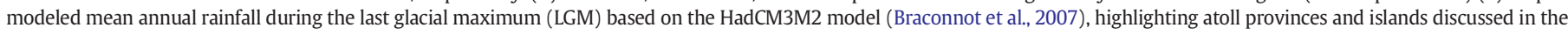

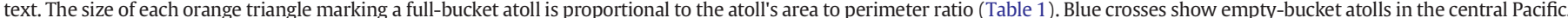

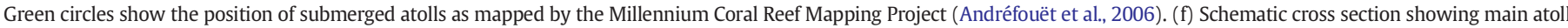

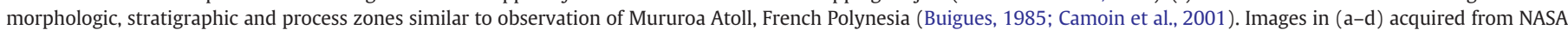
(LANDSAT-7, EO-1, MODIS and ISS, respectively).

Fig. 1e), and, therefore would be expected to experience greater potential dissolution during lowstands. In contrast, the largest full-bucket atolls often occur within the equatorial dry belt (i.e. Kiritimati and Starbuck Atolls), where rainfall and rates of dissolution are likely considerably lower (Fig. 1e). In contrast, differential thermal subsidence due to hot spot/crustal age does not offer a feasible alternative mechanism for driving development of full or empty-bucket atolls. For instance, the Marshall Islands (Eocene) and southern Tuamotus (Miocene) are morphologically similar (Fig. 1e) despite differing substantially in age, and therefore expected thermal subsidence rate (Detrick and Crough, 1978; Stein and Stein, 1992).

Preservation of marine isotope stage (MIS) 5e highstand deposits 1-2 meters above sea level (masl) on the rim of Kiritimati Atoll (Line Islands; Fig. 1d; Woodroffe and McLean, 1998) can likely also be attributed to dry conditions (Table 1). Although emergent rims in the Line
Islands could result from slow atoll subsidence or uplift, a gradient in maximum rim elevation (Malden, 15 masl; Jarvis, 7 masl; Christmas, 13 masl; Fanning, 4 masl; Washington, 5 masl; Palmyra, 2 masl; Kingman Reef, 1 masl) and rainfall (Table 1) moving from atolls near the equator towards the Inter-tropical Convergence Zone (ITCZ) (Keating, 1992) northward strongly suggests that these features are dissolution, not vertical motion, derived. Atoll rims well above modern sea level are also observed on many of the Phoenix Islands (Davis, 1928; $1700 \mathrm{~km}$ west of the Line Islands), which straddle the equator and typically receive $\sim 1 \mathrm{~mm} /$ day or less of rainfall (Table 1 ). Drilling efforts on modern full-bucket atolls that receive more moderate rainfall have recovered MIS 5e deposits well below the modern rim (Enewetak, 8-14 m; Tarawa, 8-14 m; Mururoa, 9-24 m; Northern Cook Islands, 18-28 m; Dickinson, 2004, and refs. therein), likely indicating substantial dissolution through those deposits. Located far from active tectonic 
Table 1

Locations and characteristics of islands classified as "full-buckets" on the basis of satellite imagery.

\begin{tabular}{|c|c|c|c|c|c|c|c|c|}
\hline Chain & Island & Type & LON (dd) & LAT (dd) & Area $\left(\mathrm{km}^{2}\right)$ & Perimeter (km) & $\mathrm{A} / \mathrm{P}(\mathrm{km})$ & Mean rainfall (mm/day) \\
\hline Tuvalu & Nanumanga & Brackish & 176.321 & -6.287 & 5.9 & 13.0 & 0.5 & 5.1 \\
\hline Tuvalu & Niutao & Filled & 177.343 & -6.108 & 4.6 & 10.4 & 0.4 & 4.6 \\
\hline Tuamotu & Puka Puka & Shallow & -138.817 & -14.820 & 21.7 & 24.8 & 0.9 & 3.0 \\
\hline Tuamotu & Tekokota & Shallow & -142.570 & -17.310 & 10.1 & 15.5 & 0.7 & 5.1 \\
\hline Tuamotu & Tehuata & Shallow & -141.921 & -16.836 & 6.9 & 13.1 & 0.5 & 4.7 \\
\hline Tuamotu & Nukutavake & Filled & -138.787 & -19.281 & 8.7 & 17.5 & 0.5 & 4.5 \\
\hline Tuamotu & Pinaki & Shallow & -138.675 & -19.394 & 4.9 & 10.0 & 0.5 & 4.5 \\
\hline Tuamotu & Akiaki & Filled & -139.213 & -18.559 & 2.8 & 8.2 & 0.3 & 4.4 \\
\hline Tuamotu & Tepoto North & Filled & -141.430 & -14.430 & 3.2 & 9.9 & 0.3 & 3.9 \\
\hline Phoenix & Sydney & Shallow & -171.244 & -4.455 & 12.5 & 18.9 & 0.7 & 1.1 \\
\hline Phoenix & Enderbury & Brackish & -171.085 & -3.126 & 9.7 & 17.7 & 0.5 & 0.5 \\
\hline Phoenix & Baker & Filled & -176.479 & 0.194 & 5.7 & 11.7 & 0.5 & 0.2 \\
\hline Phoenix & Howland & Filled & -176.618 & 0.808 & 4.5 & 12.0 & 0.4 & 0.6 \\
\hline Phoenix & Rawaki & Brackish & -170.715 & -3.724 & 2.3 & 8.1 & 0.3 & 0.8 \\
\hline Phoenix & McKean & Brackish & -174.122 & -3.596 & 1.7 & 6.3 & 0.3 & 0.8 \\
\hline Phoenix & Birnie & Filled & -171.516 & -3.587 & 2.3 & 9.0 & 0.3 & 0.7 \\
\hline Marshalls & Mejit & Filled & 170.870 & 10.287 & 9.6 & 16.5 & 0.6 & 3.6 \\
\hline Marshalls & Lib & Shallow/Brackish & 167.380 & 8.314 & 2.4 & 8.1 & 0.3 & 8.8 \\
\hline Marshalls & Jemo & Filled & 169.546 & 10.093 & 6.0 & 21.8 & 0.3 & 3.9 \\
\hline Marshalls & Kili & Filled & 169.120 & 5.643 & 3.0 & 11.0 & 0.3 & 11.6 \\
\hline Marshalls & Jabat & Filled & 168.977 & 7.754 & 2.5 & 9.4 & 0.3 & 10.2 \\
\hline Line & Christmas & Brackish/Shallow & -157.381 & 1.871 & 695.8 & 192.0 & 3.6 & 0.6 \\
\hline Line & Malden & Shallow & -154.928 & -4.017 & 43.6 & 40.7 & 1.1 & 0.7 \\
\hline Line & Starbuck & Filled/Brackish & -155.880 & -5.639 & 35.1 & 36.1 & 1.0 & 2.1 \\
\hline Line & Washington & Brackish & -160.394 & 4.689 & 29.7 & 34.3 & 0.9 & 6.8 \\
\hline Line & Jarvis & Filled & -159.996 & -0.373 & 6.6 & 12.2 & 0.5 & 0.1 \\
\hline Line & Flint & Filled & -151.820 & -11.430 & 4.5 & 16.1 & 0.3 & 7.2 \\
\hline Line & Vostok & Filled & -152.310 & -10.066 & 1.0 & 5.4 & 0.2 & 6.7 \\
\hline Gilberts & Beru & Shallow & 175.983 & -1.324 & 60.9 & 52.2 & 1.2 & 0.2 \\
\hline Gilberts & Kuria & Filled & 173.396 & 0.251 & 67.7 & 61.4 & 1.1 & 0.4 \\
\hline Gilberts & Nikunau & Filled & 176.452 & -1.351 & 36.4 & 53.9 & 0.7 & 0.2 \\
\hline Gilberts & Tamana & Filled & 175.984 & -2.499 & 8.4 & 17.9 & 0.5 & 0.2 \\
\hline Gilberts & Arorae & Filled & 176.820 & -2.637 & 15.8 & 34.4 & 0.5 & 0.3 \\
\hline Cook & Nassau & Filled & -165.415 & -11.561 & 2.6 & 8.3 & 0.3 & 10.9 \\
\hline Carolines & Fais & Filled & 140.520 & 9.763 & 5.9 & 11.7 & 0.5 & 8.5 \\
\hline Carolines & Fayu & Filled & 151.340 & 8.549 & 4.6 & 10.2 & 0.4 & 9.4 \\
\hline Carolines & Losiep & Filled/Shallow & 139.833 & 9.923 & 8.0 & 18.3 & 0.4 & 8.4 \\
\hline Carolines & Satawal & Filled & 147.034 & 7.382 & 3.7 & 11.2 & 0.3 & 11.7 \\
\hline Carolines & Gaferut & Filled/Shallow & 145.384 & 9.229 & 2.0 & 7.2 & 0.3 & 8.8 \\
\hline Carolines & Nama & Filled & 152.577 & 6.993 & 3.1 & 11.6 & 0.3 & 11.7 \\
\hline
\end{tabular}

boundaries, only a fraction of the offset between the modern position of last inter-glacial reef deposits on these islands and maximum MIS 5e sea level (>4 masl, Kopp et al., 2013) can be attributed to thermal subsidence (Stein and Stein, 1992), suggesting relatively rapid rates of dissolution over the past $\sim 125$ kyrs.

Although simple numerical reef models (e.g., Bosence and Waltham, 1990; Chappell, 1980; Koelling et al., 2009; Paulay and McEdward, 1990) have been widely used to explore the dominant controls on the morphology of reef-bound volcanic islands during the late Pleistocene, a lack of late Miocene (and earlier) sea-level records has limited similar application to atolls. Here we use a simple numerical model to explore the most likely sea-level histories since the late Miocene $(<8.5 \mathrm{Ma})$ that are consistent with observed core stratigraphy from Enewetak Atoll. We then examine the controls on modern atoll morphology (subsidence, dissolution or sea-level variability) and identify the relative process rates that have led to the formation of "empty-bucket" versus "full-bucket" atolls today and in the geologic past.

\section{Materials and methods}

\subsection{Overview}

We use a numerical box model consisting of two reservoirs, representing rim and lagoon elevations, to test the relative contributions of subsidence, dissolution and sea-level variability in determining reef form. This model is similar to, but simpler than, previous models used to study the evolution of island atoll systems (e.g., Montaggioni et al., 2015; Quinn, 1991a; Toomey et al., 2013; Warrlich et al., 2002).
An overview is given here, with a more detailed description provided below (Sections 2.2-2.5).

Both elevation nodes, the rim and lagoon, experience subsidence and, additionally, erosional surface lowering from dissolution when they are subaerially exposed (defined by a typical proportion of dissolution relative to local rainfall). The carbonate accretion rate on the atoll rim decreases as water depth increases due to light attenuation ( $15-$ 30 meters below sea level-mbsl) in the water column (Bosscher and Schlager, 1992). Sediment deposited in the lagoon derives from in situ carbonate production as well as from the transport of reef material from the rim by waves. Lagoonal sedimentation only occurs when the rim is below a minimum depth allowing for free exchange of water and nutrients between the lagoon and the open ocean. In the model, in situ production occurs across the lagoon, accumulating within the lagoon box at a fixed rate independent of lagoon area; however, the flux of rim-derived, wave-transported sediment is controlled by the atoll's geometry, and vertical accumulation in the lagoon therefore depends on the ratio of lagoon area to the area of carbonate production along the atoll rim (e.g., Purdy and Winterer, 2001, and refs. therein). We assume that the footprint of each atoll remains fixed over the duration of the model run.

The model was calibrated and tested in three main steps using corelogs and bathymetry from multiple data sources: (1) rates of dissolution of the atoll rim and subsidence within the model were calibrated over the mid-late Pleistocene ( $<2 \mathrm{Ma}$; Fig. 2) using stratigraphy from Enewetak Atoll. (2) Markov Chain Monte Carlo methods were used to iteratively solve for the sea-level history since $8.5 \mathrm{Ma}$ as well as the lagoon dissolution rate that best fit corelog stratigraphy from Enewetak 

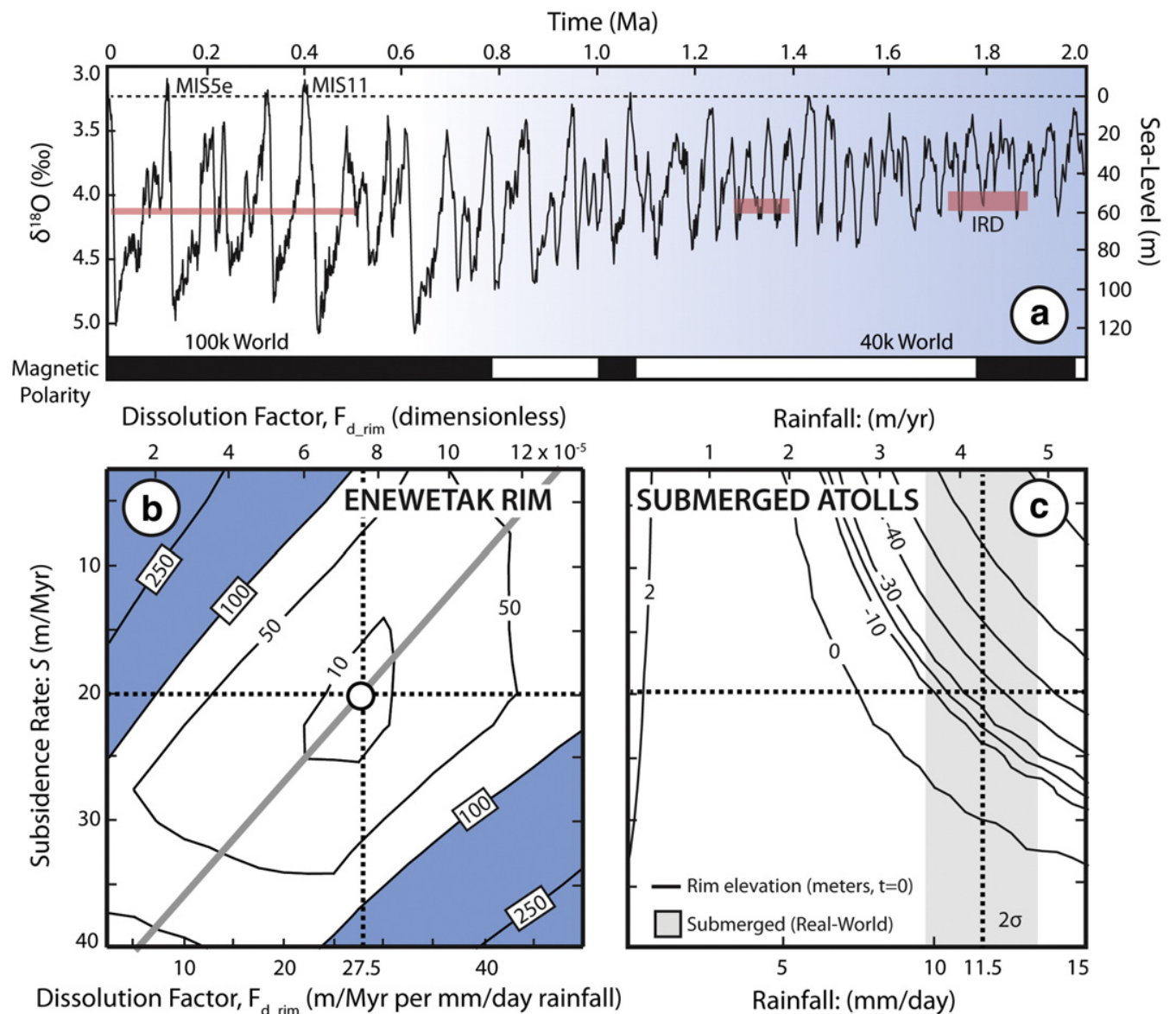

Strat v. Model MSE $\left(\mathrm{m}^{2}\right)$

Rim Elevation (masl)

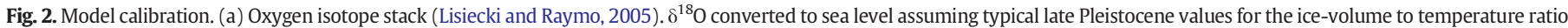

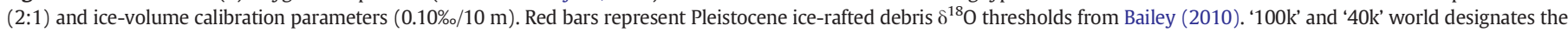

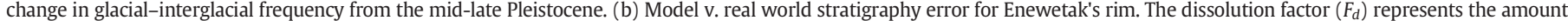

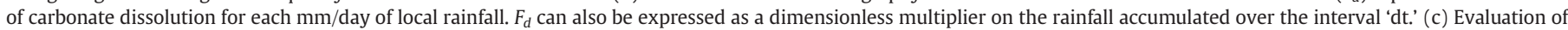

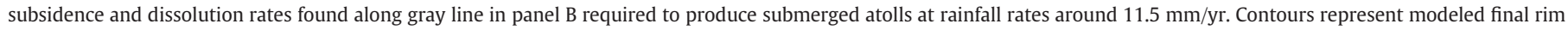
elevation in meters.

Atoll (Wardlaw and Quinn, 1991) (Fig. 3). (3) Lagoon depths produced by the model for different atoll sizes and dissolution rates were compared to a dataset of real-world observations from the Gilbert, Caroline and Marshall Island chains (Fig. 4). This multi-step approach greatly increased numerical efficiency by allowing for targeted calibration of model components using specific real-world datasets described in further detail below.

\subsection{Model formulation}

Fig. 1f illustrates the model domain and the processes (e.g., reef accretion, subsidence, dissolution, sedimentation) that shape the elevation of the atoll lagoon and rim. Assuming the lagoon and rim maintain fixed horizontal areas ( $a_{l}$ and $a_{r}$ respectively), the model simulates the time evolution of their surface heights $z(t)$ from a fixed compensation depth as:

$\frac{d z_{l}}{\mathrm{dt}}=C_{l}(\mathrm{t})-E_{l}(\mathrm{t})-\mathrm{S}$

$\frac{d z_{r}}{\mathrm{dt}}=C_{r}(\mathrm{t})-E_{r}(\mathrm{t})-\mathrm{S}$

where $C$ is the accumulation rate of carbonate sediment (lagoon) or reef framework (rim), $E$ is the rate of vertical dissolution (subaerial erosion) at time ' $t$ ', $S$ is the subsidence rate, and subscripts $r$ and $l$ refer to the rim and lagoon, respectively. A constant rate of subsidence, approximating long-term lithospheric cooling (Detrick and Crough, 1978; Parsons and Sclater, 1977; Stein and Stein, 1992), is applied throughout each model run (parameters used are summarized in Table 4). We relate dissolution to local rainfall using a conversion factor $F_{d}$. Rainfall for each site was linearly scaled between the Last Glacial Maximum (LGM) and Pre-Industrial rates (HadCM3M2, Braconnot et al., 2007; Gordon et al., 2000) in proportion to ice volume at time ' $t$ '. Comparison of available proxy and general circulation model data suggest HadCM3 output closely matches the pattern of rainfall change between the LGM and PreIndustrial in the Western Tropical Pacific (DiNezio and Tierney, 2013).

Carbonate dissolution occurs when the rim, or the rim and lagoon, are exposed above sea level. Although channeling of rainwater likely leads to spatially heterogeneous dissolution across real-world rims and lagoons over any given glacial lowstand, this is likely balanced by focusing of sediment into topographic lows during subsequent interglacial flooding. Local water depth above or below the rim $\left(d_{r}\right)$ is defined as.

$d_{r}=S L(\mathrm{t})-z_{r}(\mathrm{t})$ 


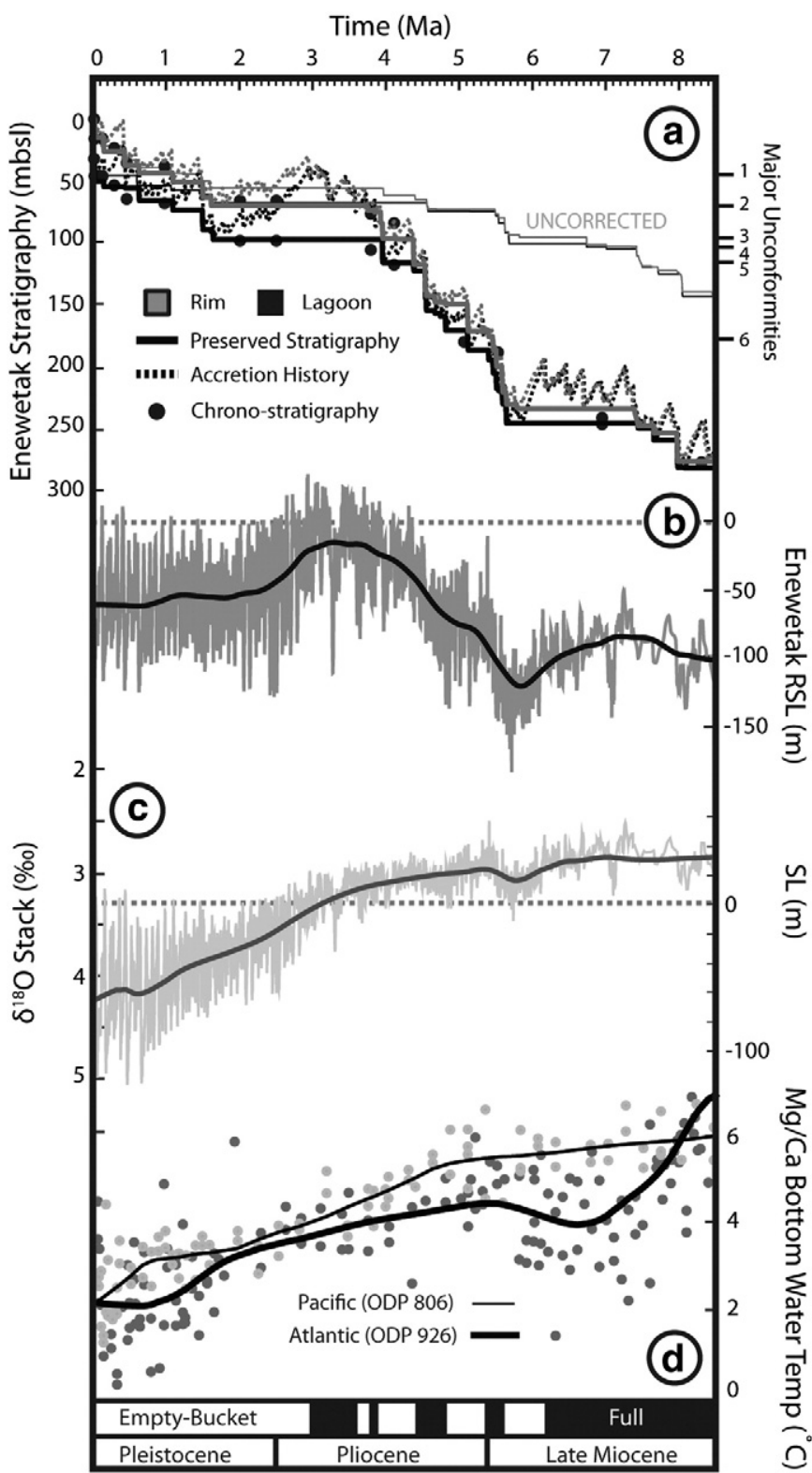

Fig. 3. Enewetak Atoll stratigraphy and relative sea-level history. (a) Model fit to Enewetak corelogs. Thick solid black and gray lines represent the preserved model lagoon and rim stratigraphy, respectively, run with the corrected sea-level curve shown in panel 'b'. Dashed black and gray lines show the subsidence corrected accretion and dissolution history. Thin solid black and gray lines show modeled stratigraphy generated using sealevel curve (panel c) based on $\delta^{18} \mathrm{O}$ corrected using late Pleistocene calibration parameters only but the same subsidence and dissolution parameters as above. Black dots indicate bio-stratigraphic tie points for the KAR-1 core (bottom of lagoon) and combined XEN-3 and F-1 cores (top of rim). Unconformities in KAR-1 (lagoon) are taken from Wardlaw and Quinn (1991). (b) Best-fit model relative sea-level curve (medium gray). (c) Light gray line shows the $\delta^{18} \mathrm{O}$ stack and its equivalent sea level using late Pleistocene calibration parameters. (d) Deep-ocean $\mathrm{Mg} / \mathrm{Ca}$ temperature reconstructions from the Pacific (thin line, light gray circles) and Atlantic (thick line, dark gray circles) (LaRiviere et al., 2012; Lear et al., 2003). Dark solid lines in panels b-d show LOWESS filter (Cleveland, 1979) of the underlying data.

We compute sea level $(S L)$ over millennial timescales by applying long-term deep ocean temperature $(T)$ and ice volume/temperature corrections $\left(I_{c}\right)$ to the $\Delta \delta^{18} \mathrm{O}$ stack:

$S L(\mathrm{t})=I_{c}(\mathrm{t})\left[\Delta \delta^{18} \mathrm{O}(\mathrm{t})+T(\mathrm{t})\right]$

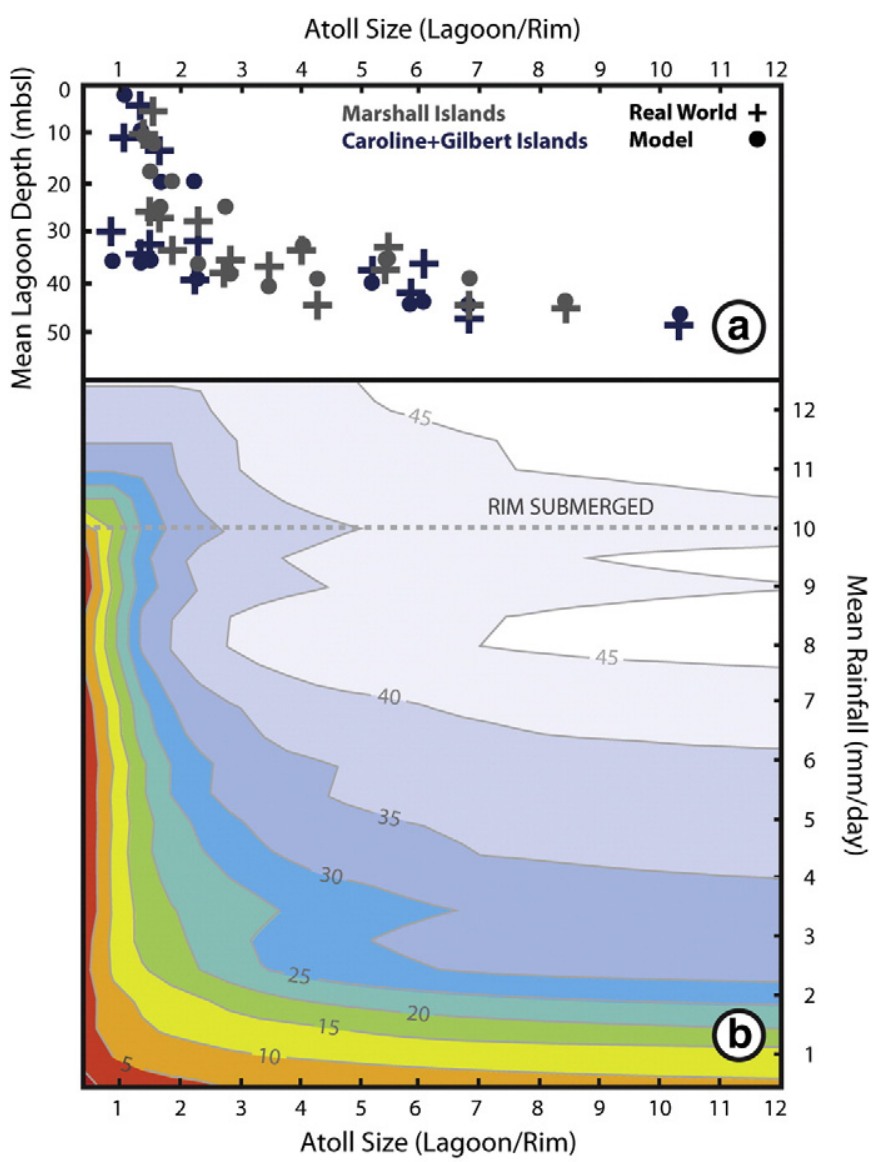

LAGOON DEPTH (mbsl)

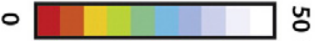

Fig. 4. Influence of atoll size and rainfall on lagoon depth. (a) Comparison of observed spatial mean modern lagoon depth and modeled lagoon depth as a function of atoll lagoon-rim area ratio for the study atolls indicated in Table 2. (b) Plot of modeled modern lagoon depth versus mean rainfall rate and rim sediment input (for which atoll size is a proxy). Subsidence was $20 \mathrm{~m} / \mathrm{Myr}$ for these model runs. For panel b rainfall was held constant.

where $\Delta \delta^{18} \mathrm{O}$ is the difference between modern benthic $\delta^{18} \mathrm{O}$ and the value at time $t$. $I_{c}$ accounts for the proportion of $\Delta \delta^{18} \mathrm{O}$ due to ice volume changes (not temperature) and a scaling factor (typically $10 \mathrm{~m} / 0.1 \%$ $\Delta \delta^{18} \mathrm{O}$; Miller et al., 2012). Each equation is solved forward in time using an explicit finite difference approximation with a time step of $100 \mathrm{yr}$.

When the rim is submerged below sea level $\left(d_{r}<S L\right)$, the rate of carbonate accumulation on the atoll $\operatorname{rim}\left(C_{r}\right)$ is calculated using an equation similar to Bosscher and Schlager's (1992) formulation for coral growth as a function of water depth:

$$
\begin{array}{ll}
C_{r}=A_{\max } \tanh \left[\frac{I_{0}}{I_{k}}\left(1-\frac{D m}{d}\right) e^{-k d}\right] d r \geq D m \\
C_{r}=0 \quad d_{r}<D m
\end{array}
$$

where $A_{\max }$ is the maximum reef accretion rate $(\mathrm{m} / \mathrm{yr}), I_{0}$ is the surface light intensity $\left(\mu \mathrm{Em}^{-2} \mathrm{~s}^{-1}\right), k$ is the light extinction coefficient $\left(\mathrm{m}^{-1}\right), I_{k}$ is the saturating light intensity $\left(\mu \mathrm{Em}^{-2} \mathrm{~s}^{-1}\right)$ and $D_{m}$ is the minimum depth needed for free water exchange over the rim. We use an accretion rate $\left(A_{\max }\right)$, the vertical build-up of reef framework as well as rubble/ sediment, of $5 \mathrm{~mm} / \mathrm{yr}$, in line with observations at Enewetak (Szabo et al., 1985) and throughout the Pacific (Montaggioni, 2005). While faster Holocene rates $(\geq 10 \mathrm{~mm} / \mathrm{yr}$ ) of accretion are observed in 
individual drill cores at Enewetak and elsewhere (Montaggioni, 2005), such fast accretion rates would likely over-estimate the instantaneous accretion rate of the entire atoll rim. Other parameters are similar to those originally proposed by Bosscher and Meester (1992). Altogether, this equation yields high accretion rates for water depths less than 10 to $15 \mathrm{~m}$, with accretion rate rapidly decreasing at greater depths.

In the model, lagoon sediment derives from in situ, primary production $(P)$ and rim-transported material. A scaling factor is applied to the rim-derived sediment based on the area ratio of lagoon $\left(a_{l}\right)$ to $\operatorname{rim}\left(a_{r}\right)$ (e.g., Daly, 1910; Purdy and Winterer, 2001):

$C_{l}=P+R_{s} \frac{a_{l}}{a_{r}} d_{r}>D_{m}$

$C_{l}=0 \quad d_{r} \leq D_{m}$

where $C_{l}$ is the total lagoon sedimentation rate and $R_{S}$ represents the unscaled rim-derived sediment infill rate, which we determine empirically (Section 2.5). Sedimentation does not occur when the rim exceeds a minimum depth $\left(D_{m}\right)$ needed for water exchange with the lagoon, consistent with stratigraphic and field observation (Tables 3, 4). For example, none of the sedimentary sequences recovered from Enewetak's lagoon (Henry and Wardlaw, 1987; Henry et al., 1986) show evidence of deposition between MIS 5e and the Holocene, indicating that either sedimentation is minimal when the rim is exposed and the flow of ocean water into the lagoon is restricted, or lowstand lagoon sediments may be organic-rich gyttja (observed in meromictic atoll lakes today, e.g., Sachs et al., 2009) that is rapidly oxidized once exposed. By analogy, widespread hard bottom at Lake Tengano, Rennell Island (Christiansen, 1964), an uplifted, completely enclosed (rim 100 masl) atoll in the Solomon Islands, indicates that minimal deposition occurs if the lagoon is restricted. Additionally, in the model, sediment deposition does not occur if the lagoon elevation would then exceed that of the rim. This assumes that, without the sheltering of the rim, wave stirring and associated currents across the lagoon would prevent deposition of relatively fine-grained lagoon sediment.

\subsection{Atoll morphology}

A dataset of morphologic characteristics was compiled for 28 atolls in the Marshall, Gilbert and Caroline chains (Table 2) from published charts as well as morphologic surveys completed as part of the Millennium Coral Reef Mapping Project (Andréfouët et al., 2006). At present, atoll lagoons across much of the Pacific remain relatively poorly mapped, so we chose to focus on these three atoll chains owing to the extensive mapping efforts archived by the UK Hydrographic Office and the National Geospatial-Intelligence Agency (US). Submerged atolls identified in Fig. 1e were drawn from the Millennium Coral Reef Mapping Project, whereas filled atolls, not including makatea islands, were identified based on subjective visual criteria using Google Earth ${ }^{\mathrm{TM}}$ and satellite bathymetry (Robinson et al., 2000).

We followed a similar approach to Purdy and Winterer (2001)) in compiling our dataset of lagoon depths, but we only included islands with complete spatial coverage and more than 100 bathymetric soundings across the lagoon. We also excluded islands in areas of apparent past or ongoing active tectonics. Charted depths were digitized in ArcGIS (Esri, Redlands, California) in order to calculate a spatial mean depth for each atoll's lagoon. Similar to previous efforts (Purdy and Winterer, 2001), Nukuoro was excluded because its lagoon depth represents a major outlier, particularly in comparison with nearby islands (e.g., Satawan, Luknor) that have likely experienced similar environmental conditions.

\subsection{Enewetak stratigraphy}

A composite stratigraphy for Enewetak was compiled using existing U-series (Szabo et al., 1985), biostratigraphic (Bybell and Poore, 1991) and strontium isotope (Ludwig et al., 1988; Quinn et al., 1991) information available in the literature. In general, we followed the approach of Wardlaw and Quinn (1991) but updated the timing of identified large nanofossil datums using recent chronology (Raffi et al., 2006). Rim stratigraphy was based on three datasets: (1) core XEN-3, taken on Enjebi island as part of the EXPOE program (Couch et al., 1975), was used to constrain chronology in the upper part $(0-83.8 \mathrm{~m})$ of the rim while

Table 2

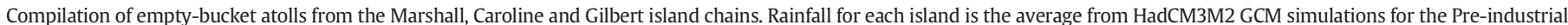
and Last Glacial Maxim (Braconnot et al., 2007). Rainfall data is available online from: https://pmip2.lsce.ipsl.fr/.

\begin{tabular}{|c|c|c|c|c|c|c|c|}
\hline Name & Island & LON (dd) & LAT (dd) & Atoll area $\left(\mathrm{km}^{2}\right)$ & Lagoon area $\left(\mathrm{km}^{2}\right)$ & Mean depth (m) & Mean rainfall ( $\mathrm{mm} /$ day) \\
\hline Marshall & Enewetak & 162.227 & 11.501 & 1074.0 & 908.6 & 33.1 & 3.4 \\
\hline Marshall & Ujelang & 160.894 & 9.824 & 108.5 & 68.2 & 27.1 & 5.4 \\
\hline Marshall & Bikini & 165.386 & 11.598 & 749.1 & 633.1 & 38.1 & 2.9 \\
\hline Marshall & Ailuk & 169.936 & 10.325 & 254.6 & 187.2 & 38.5 & 3.6 \\
\hline Marshall & Arno & 171.680 & 7.083 & 461.9 & 342.2 & 36.2 & 10.9 \\
\hline Marshall & Aur & 171.097 & 8.254 & 284.7 & 231.1 & 45.1 & 8.7 \\
\hline Marshall & Maleolap & 171.047 & 8.728 & 1043.0 & 932.7 & 46.0 & 7.4 \\
\hline Marshall & Bikar & 170.107 & 12.245 & 65.9 & 38.6 & 9.9 & 1.8 \\
\hline Marshall & Likiep & 169.138 & 9.909 & 504.6 & 405.2 & 34.1 & 4.2 \\
\hline Marshall & Majuro & 171.190 & 7.125 & 374.1 & 291.1 & 37.1 & 11.0 \\
\hline Marshall & Taka & 169.622 & 11.153 & 147.5 & 96.4 & 33.8 & 2.9 \\
\hline Marshall & Utirik & 169.791 & 11.259 & 110.4 & 66.6 & 25.8 & 2.8 \\
\hline Marshall & Taongi & 168.964 & 14.655 & 122.0 & 74.8 & 5.4 & 1.9 \\
\hline Marshall & Wotje & 170.021 & 9.450 & 809.5 & 706.5 & 45.2 & 5.5 \\
\hline Carolines & Ant & 157.961 & 6.780 & 101.8 & 71.1 & 27.7 & 11.7 \\
\hline Carolines & Kapingmarangi & 154.766 & 1.069 & 78.1 & 54.1 & 40.1 & 3.0 \\
\hline Carolines & Lamotrek & 146.323 & 7.489 & 51.6 & 31.2 & 32.7 & 11.6 \\
\hline Carolines & Losap & 152.701 & 6.878 & 51.3 & 29.6 & 34.9 & 11.8 \\
\hline Carolines & Lukunor & 153.760 & 5.522 & 75.2 & 52.5 & 31.9 & 12.6 \\
\hline Carolines & Satawan & 153.596 & 5.402 & 428.4 & 366.0 & 42.8 & 12.7 \\
\hline Carolines & Murilo & 152.214 & 8.680 & 413.9 & 355.5 & 36.4 & 9.1 \\
\hline Carolines & Namonuito & 150.080 & 8.708 & 2145.2 & 1956.6 & 48.8 & 9.3 \\
\hline Carolines & Nomwin & 151.779 & 8.534 & 345.6 & 290.1 & 37.9 & 9.4 \\
\hline Carolines & Oroluk & 155.295 & 7.519 & 476.1 & 415.4 & 47.6 & 11.3 \\
\hline Carolines & Woleai & 143.867 & 7.353 & 55.3 & 26.1 & 29.7 & 11.6 \\
\hline Gilbert & Abemama & 173.862 & 0.400 & 287.5 & 150.2 & 11.1 & 0.5 \\
\hline Gilbert & Butaritari & 172.820 & 3.167 & 442.5 & 278.7 & 13.7 & 4.9 \\
\hline Gilbert & Tarawa & 172.991 & 1.450 & 553.2 & 319.4 & 4.2 & 1.5 \\
\hline
\end{tabular}


(2) cores F-1, E-1 and K-1B from the original coring of Enewetak Atoll (Ladd et al., 1953; Lincoln and Schlanger, 1987) and seismic stratigraphy from KOA crater (Folger, 1986) were used for lower sections. Lagoon stratigraphy was based on detailed ${ }^{87} \mathrm{Sr} /{ }^{86} \mathrm{Sr}$ measurements (Ludwig et al., 1988; Quinn et al., 1991) and biostratigraphy in core KAR-1 (Bybell and Poore, 1991) taken as part of the PEACE program (Henry and Wardlaw, 1990). Correlation between the chronometers in various boreholes is possible using local biostratigraphic indicators (Cronin et al., 1986) and unconformities (Henry et al., 1986). A summary of chronometers used in this study can be found in Table 3.

\subsection{Model calibration}

As a first step, we drove the model with a Pleistocene (0-2 Ma) sealevel record using a wide range of potential subsidence and rim dissolution rates, and identified the combination of these rates that produced the closest match to Enewetak Atoll rim stratigraphy over the same time interval (Table 3). We chose the 0 to $2 \mathrm{Ma}$ time interval because it offers the best age control within Enewetak's stratigraphic record and because a reasonable estimate of eustatic sea level can likely be made by converting the $\delta^{18} \mathrm{O}$ stack using late Pleistocene ice volume and temperature values (2:1 ice volume to temperature ratio and $10 \mathrm{~m} /$ $0.1 \% \Delta \Delta \delta^{18} \mathrm{O}$ ).

Both subsidence and dissolution can create accommodation space for reef growth. The best-fit model rim dissolution and island subsidence rates calibrated using stratigraphy from core XEN-3 (Henry and Wardlaw, 1987) therefore occur along a line (Fig. 2b) representing how lower (higher) subsidence rates are balanced in the model by higher (lower) dissolution rates to match the recorded stratigraphy. Final $(t=0)$ rim elevations (Fig. 2c) for combinations of possible subsidence rates and rim dissolution factors taken along this line (Fig. 2b) were then compared to observations of real world rim submergence which occur as rainfall rates approach $11.5 \pm 0.9 \mathrm{~mm} / \mathrm{yr}$ (Fig. 1e). After calibrating the subsidence and rim dissolution rates, a total lagoon sedimentation rate (in situ + rim derived) was estimated by running the model from deglacial flooding of the $\operatorname{rim}(\sim 10 \mathrm{kyr} B P)$ to present.

Next, we used a standard Metropolis Sampler (Chib and Greenberg, 1995; Metropolis et al., 1953) Markov Chain-Monte Carlo (MCMC) approach, to (1) determine if faster rates of lagoon sediment dissolution, relative to rim reef framework, may have contributed to the development of modern deep bucket atolls and (2) produce 1000 possible sea-level records for the past $8.5 \mathrm{Ma}$. The elevation of the lagoon, $\mathrm{z}_{1}$

\section{Table 3}

Chronologic constraints on Enewetak stratigraphy. All tie points between cores are based on local biostratigraphic and ${ }^{87} \mathrm{Sr} /{ }^{86} \mathrm{Sr}$ data except for the rim KK/LL transition $(275.6$ $\mathrm{mbsl}$ ), which is based on seismic reflector R90 and biostratigraphy from core KBZ-4. Stratigraphic horizons below $220 \mathrm{mbsl}$ are not thought to have sustained significant deformation or subsidence during nuclear weapons testing (Folger, 1986). The 'Organic Interval,' which occurs at the JJ/KK transition in the PEACE cores was placed at the lower limit of transitional zone identified by Lincoln and Schlanger (1991), consistent with the $\mathrm{JJ} / \mathrm{KK}$ transition in KBZ-4 and seismic observations (Folger, 1986).

\begin{tabular}{|c|c|c|c|c|c|}
\hline $\begin{array}{l}\text { Time } \\
\text { (Ma) }\end{array}$ & Horizon & Biozone & Chronometers & $\begin{array}{l}\text { Lagoon } \\
\text { (mbsl) }\end{array}$ & $\begin{array}{l}\text { Rim } \\
\text { (mbsl) }\end{array}$ \\
\hline 0.00 & Surface & AA & Surface & 32.0 & 0.0 \\
\hline 0.01 & DIS 1 & $\mathrm{AA} / \mathrm{BB}$ & ${ }^{14} \mathrm{C}$ & 45.9 & 15.8 \\
\hline 0.12 & DIS 1 & $\mathrm{AA} / \mathrm{BB}$ & U-Series & 45.9 & 15.8 \\
\hline 0.28 & & $\mathrm{BB} / \mathrm{CC}$ & NN21-NN20 & 53.5 & 23.3 \\
\hline 0.45 & & MID. CC & U-Series, NN20-NN19 & 62.9 & 34.7 \\
\hline 1.00 & & $\mathrm{CC} / \mathrm{DD}$ & NN19-NN19a, ${ }^{87} \mathrm{Sr} /{ }^{86} \mathrm{Sr}$ & 67.7 & 38.7 \\
\hline 1.98 & DIS 3 & $\mathrm{EE} / \mathrm{FF}$ & NN19a-NN18 & 97.8 & 65.5 \\
\hline 2.51 & DIS 3 & $\mathrm{EE} / \mathrm{FF}$ & NN17-NN16 & 97.8 & 65.5 \\
\hline 3.81 & DIS 4 & $\mathrm{FF} / \mathrm{GG}$ & NN16-NN14 & 105.4 & 76.2 \\
\hline 4.13 & DIS 5 & $\mathrm{GG} / \mathrm{HH}$ & NN14-NN13 & 117.1 & 83.8 \\
\hline 5.09 & DIS 6 & $\mathrm{HH} / \mathrm{II}$ & NN13-NN12 & 178.9 & \\
\hline 5.56 & $\mathrm{PLIO} / \mathrm{MIO}$ & $\mathrm{II} / \mathrm{JJ}$ & NN12-NN11 & 216.4 & 187.5 \\
\hline 7.00 & Organic Interval & $\mathrm{JJ} / \mathrm{KK}$ & ${ }^{87} \mathrm{Sr} /{ }^{86} \mathrm{Sr}$ & 245.4 & 240.0 \\
\hline 8.36 & & $\mathrm{KK} / \mathrm{LL}$ & NN11-NN10 & 275.8 & 275.6 \\
\hline
\end{tabular}

Table 4

Model parameters used in (and determined by) numerical experiments. Dissolution is calculated by multiplying amount of rainfall over time-step, ' $\Delta \mathrm{t}$ ' by the dissolution factor $\left(F_{d}\right)$.

\begin{tabular}{llll}
\hline Parameter & Symbol & Value & Units \\
\hline Timestep & $\mathrm{dt}$ & 100 & $\mathrm{yr}$ \\
Max accretion rate & $G_{m}$ & 0.005 & $\mathrm{~m} / \mathrm{yr}$ \\
Surface light intensity & $I_{o}$ & 2000 & $\mu \mathrm{Em}^{-2} \mathrm{~s}^{-1}$ \\
Saturating light intensity & $I_{k}$ & 350 & $\mu \mathrm{Em}^{-2} \mathrm{~s}^{-1}$ \\
Light extinction coef. & $k$ & 0.1 & {[]} \\
Rim minimum depth & $D_{m}$ & 2 & $\mathrm{mbsl}$ \\
Subsidence & $S$ & 20 & $\mathrm{~m} / \mathrm{Myr}$ \\
Erosion factor (rim, lagoon) & $F_{d}$ & $7.5 \mathrm{e}^{-5}, 10.4 \mathrm{e}^{-5}$ & {[]} \\
Primary production & $P$ & 0.003 & $\mathrm{~m} / \mathrm{yr}$ \\
Transported sediment & $R_{S}$ & 0.001 & $\mathrm{~m} / \mathrm{yr}$ \\
\hline
\end{tabular}

(t) is not sufficiently constrained after 8.5 Ma, given Enewetak's transition to an empty-bucket atoll, to set an initial condition for the model due to the effects of post-depositional dissolution on the preserved lagoon stratigraphy, discussed further in Section 3.2. As our 'Prior,' $I_{c}$ and $T$, the ice-volume and deep ocean temperature parameters used to convert $\Delta \delta^{18} \mathrm{O}$ stack to sea level, were adjusted to bring Pleistocene and late Pliocene ice-rafted debris thresholds (Bailey et al., 2010; Flesche Kleiven et al., 2002) into alignment and account for a $\sim 4-5{ }^{\circ} \mathrm{C}$ degree decrease in bottom water temperatures between the late Miocene and Pliocene (Lear et al., 2003) (linearly applied here). Lagoonal and rim dissolution factors were initially set equal. Throughout the MCMC experiment, ice volume and temperature corrections for 0 to $0.5 \mathrm{Ma}$ were held at conventional late Pleistocene values $(\sim 2: 1$ ice volume to temperature; $\left.10 \mathrm{~m} / 0.1 \% \Delta \delta^{18} \mathrm{O}\right)$ and a maximum midPliocene Warm Period highstand (2.9-3.2 Ma) between 12 and 32 masl (Miller et al., 2012) was enforced due to an unconformity in the Enewetak section over the late Pliocene (Fig. 3a).

An initial simulation ( $\operatorname{Run}_{0}$ ) was run using the above constraints for the lagoon dissolution rate $\left(F_{d l}\right)$, as well as assumed ice volume $\left(I_{c}\right)$ and deep-ocean temperature $(T)$ corrections (independently defined at $2 \mathrm{Myr}$ intervals) for converting the benthic $\Delta \delta^{18} \mathrm{O}$ stack (e.g., Lisiecki and Raymo, 2005; Zachos et al., 2001) to sea level (Eq. 3). A fit $\left(X_{R u n_{0}}{ }^{2}\right)$ between the resulting model stratigraphy and published core accumulation histories from Enewetak Atoll (Fig. 3a; Table 3) (Wardlaw and Quinn, 1991) was then evaluated using a cost function which takes a form similar to the chi-squared test statistic. Next, we proposed a new set of values for the parameters above $\left(F_{d l}, I_{c}, T\right)$ randomly drawn from a fixed search distance from their current values and, again, ran the model $\left(\operatorname{Run}_{1}\right)$ to produce a new synthetic corelog stratigraphy. The newly proposed parameters ( Run $_{1}$ ) were accepted for: (1) combinations that produced a better fit to corelog stratigraphy than the parameters from the last 'accepted' iteration or (2) the exponential change in the fit exceeded a random number drawn from a uniform distribution $(0,1)$. Accepted parameters were saved and a new set proposed. Repeated many times ( $\mathrm{n}$ runs), the model minimizes the cost and identifies a range of parameter combinations that produce stratigraphy closely matching Enewetak's.

Next, we compared lagoon depths produced by the model for islands of different size to an observational dataset of atoll bathymetric surveys from the western Pacific Ocean $(\mathrm{n}=28$; Table 2$)$. Study atolls span a range of sizes (26 to $1957 \mathrm{~km}^{2}$ ) and rainfall regimes (1.7 to $12.7 \mathrm{~mm}$ /day mean rainfall), are well mapped and located far from active tectonic boundaries. For each modeled island, we used the best-fit subsidence, dissolution (scaled for local rainfall) and sea-level parameters from the 1000 sets produced in the experiments described above. We split the observational dataset from the western Pacific Ocean into two groups, first, using the Caroline and Gilbert Islands $(n=13)$ to calculate the relative contribution of primary $(P) \mathrm{v}$. rim-derived $\left(R_{S}\right)$ contribution to the total sedimentation rate used for modeling Enewetak stratigraphy above. Observations from the Marshall Islands $(n=14$, 
excluding Enewetak) were then compared to model-generated lagoon depths to provide an overall, independent test of the model formulation. Altogether, this process yields two key results: a relative sea-level (RSL) curve extending from the late Miocene to the present (Fig. $3 \mathrm{~b}$ ) and a simple, calibrated, atoll formation model.

\section{Results and discussion}

\subsection{Subsidence and rim dissolution rates}

Stratigraphic and morphologic constraints on the model, outlined above (Section 2.5), suggest an island subsidence rate around $20.0 \mathrm{~m} /$ Myr for Enewetak Atoll, consistent with findings by previous authors. For example, basalt dated to $56.4 \pm 5 \mathrm{Ma}$ (Kulp, 1963; Lincoln and Schlanger, 1991) recovered from 1267 m below Enewetak's rim (Ladd and Schlanger, 1960) suggests a long-term mean subsidence rate between 20.6 and $24.6 \mathrm{~m} / \mathrm{Myr}$. Plate cooling models (Stein and Stein, 1992) predict a subsidence rate of $14-18 \mathrm{~m} / \mathrm{Myr}$ over the past $8.5 \mathrm{Ma}$ for Enewetak, assuming thermal reset of the crust during island formation (Detrick and Crough, 1978; Li et al., 2004). Likewise, a mean subsidence rate of $19.5 \mathrm{~m} / \mathrm{Myr}$ since the late Cretaceous can be estimated from cores drilled on Wodejebato guyot (submerged $1485 \mathrm{mbsl}$ ), $250 \mathrm{~km}$ east of Enewetak (Larson et al., 1995). In general, long-term subsidence rates of western Pacific Ocean guyots (drowned atolls) drilled as part of ODP Leg 144 range from 15.8 to $29.0 \mathrm{~m} / \mathrm{Myr}$ (Larson et al., 1995).

The best-fit modeled rim dissolution factor $\left(F_{d r}\right)$, a dimensionless multiplier on local rainfall used to calculate dissolution is $7.5 \times 10^{-5}$ (or $27.5 \mathrm{~m} / \mathrm{Myr}$ of vertical dissolution for each $\mathrm{mm} /$ day of rainfall). Fast rim dissolution ( $93.5 \mathrm{~m} / \mathrm{Myr})$ relative to subsidence ( $20 \mathrm{~m} / \mathrm{Myr}$ ) at Enewetak (mean rainfall $=3.4 \mathrm{~mm} /$ day) is consistent with the scarcity of subaerial exposure horizons preserved in corelogs (KAR-1, 9 subaerial erosion horizons of Pleistocene age; Quinn, 1991b) relative to the much larger number depositional units that must have been produced (and presumably eroded through; Fig. 3a) over the course of the many ( 50) Pleistocene glacial/interglacial sea-level cycles indicated by the benthic $\delta^{18} \mathrm{O}$ stack (Lisiecki and Raymo, 2005, Fig. 2a). Subsequent dissolution through previously deposited interglacial units and variable highstand amplitude are recognized to cause 'missing beats' in shallow water carbonate successions (Eberli, 2013), behaviors captured by our model. Our modeled rim dissolution factor also falls between estimates for Majuro $\left(9.3 \times 10^{-5}\right)$ and Enewetak $\left(3.9 \times 10^{-5}\right)$ based on contemporary hydrologic observations in the Marshall Islands (Anthony et al., 1989). Sub-soil micro-erosion measurements on Grand Cayman Island (0.27-0.06 mm/yr) (Spencer, 1985), a potential modern analog to down-wearing during glacial-interglacial cycles, yield $F_{d}$ values between $5.7 \times 10^{-5}$ and $25.7 \times 10^{-5}$. On longer timescales, Purkis et al. (2010)) found similar dissolution rates $\left(F_{d} \sim 6.0 \times 10^{-5}\right)$ were needed to form Pleistocene karst landforms observed along the Red Sea and Arabian Gulf coasts. The mean dissolution factor calculated using cosmogenic denudation rates of MIS 5e and older corals from Barbados (Lal et al., 2005), a raised, mostly carbonate island, is $5.7 \times 10^{-5}$ assuming mean rainfall of $2.3 \mathrm{~mm} /$ day (HadCM3M2: LGM, Pre-Industrial; Braconnot et al., 2007).

\subsection{Late Miocene to present sea-level variability}

In general, the best-fit reconstructed relative sea-level curve derived from the model corrected $\delta^{18} \mathrm{O}$ stack and published drill core stratigraphy for Enewetak Atoll (Section 2.3) shows consistently low sea level throughout the late Miocene, followed by a peak in sea level during the Pliocene and a subsequent fall moving into the Pleistocene (Fig. 3b).

Beyond the numerical modeling results, basic dimensional arguments demonstrate that sea levels derived from an unadjusted $\Delta \delta^{18} \mathrm{O}$ (Fig. 3c) stack are incongruous with the stratigraphy preserved at Enewetak (Fig. 3a). Reef-derived deposits dating to $\sim 5.6,7.0$ and
8.4 Ma, found at core depths between 200-300 m below Enewetak's rim today (Fig. 3a), constrain late Miocene sea level to have been between $\sim 50-125 \mathrm{mbsl}$. Only $\sim 100 \mathrm{~m}$ of the vertical offset between present sea level and these late Miocene carbonate deposits (200-300 mbsl) can likely be accounted for by subsidence (thermal, glacial isostatic adjustment, dynamic topography). For instance, if we were instead to accept the $\Delta \delta^{18} \mathrm{O}$ stack as is and convert it to sea level using late Pleistocene ice volume/temperature calibration parameters, a subsidence rate of at least $36 \mathrm{~m} / \mathrm{Myr}$ would be needed to reconcile model stratigraphy with that observed in drill cores from Enewetak. Such a rate would be nearly twice as fast as the predicted thermal subsidence rate and observations from drowned western Pacific Ocean guyots (see Section 3.1). Ultimately, we find little evidence to support such a high subsidence rate ( $36 \mathrm{~m} / \mathrm{Myr})$, especially given the island's location far from any polar ice sheet (Mitrovica and Milne, 2002) and minimal changes in dynamic topography over the past 30 million years (Moucha et al., 2008).

Low sea-level indicators across the Miocene/Pliocene transition, distributed globally, provide further confidence that glacial conditions inferred at Enewetak Atoll during the late Miocene mainly reflects increased ice volume, not uncertainty in our estimated subsidence rate, possibly caused by regional dynamic topography or glacial-isostatic adjustment. Additional evidence of low sea level during the late Miocene is found in drill cores from Midway Atoll, $2800 \mathrm{~km}$ NE of Enewetak (Lincoln and Schlanger, 1987). There, the Miocene/Plio-Pleistocene boundary is found $\sim 146 \mathrm{~m}$ below the rim, which, corrected for subsidence, indicates sea levels at least $\sim 75 \mathrm{~m}$ below present (Ladd et al., 1970; Lincoln and Schlanger, 1987). Low late Miocene sea levels are also consistent with carbonate depositional sequences from Makatea, French Polynesia (Montaggioni and Camoin, 1997), as well as the nearly ubiquitous Miocene/early Pliocene discontinuity observed in shallow water carbonate sections worldwide (Adams et al., 1977). If the late Miocene lowstands implied by Enewetak's stratigraphy reflect eustatic sea level (ice volume) changes, a lack of corresponding heavy isotope excursions in the $\delta^{18} \mathrm{O}$ stack calls into question its utility in reconstructing sea level deep in time without substantial correction.

Much of the late Miocene $\delta^{18} \mathrm{O}$ signal appears dominated by changes in bottom water temperature (Fig. 3c, d). Our results suggest changes in deep ocean temperature $(T)$ would be needed to explain $~ 1 \%$ of the variation in the benthic $\delta^{18} \mathrm{O}$ stack during the late Miocene, consistent with independent estimates of a $\sim 4-5{ }^{\circ} \mathrm{C}$ change in deep ocean temperature (Lear et al., 2003) and the $\sim 0.55 \%$ o change in $\delta^{18} \mathrm{O}$ caused by a $\sim 2{ }^{\circ} \mathrm{C}$ warming during the last deglaciation (Fairbanks, 1989). The model also suggests the amplitude of sea-level variability was considerably lower during the late Miocene $(\sim 50 \mathrm{~m})$ than over the last few glacial cycles $(\sim 120 \mathrm{~m})$ though still much greater $(\sim 2 \times)$ than would be expected just using late Pleistocene ice volume calibration parameters. This echoes conclusions from a paired $\mathrm{Mg} / \mathrm{Ca}$ and benthic $\delta^{18} \mathrm{O}$ analysis by Billups and Schrag (2002), which suggests deep ocean temperature variability during the mid-late Miocene may have masked ice volume changes during large regressive events. Other proposed mechanisms for changing the relationship between $\Delta \delta^{18} \mathrm{O}$ and sea level include: (1) the extent of Arctic (e.g., Broecker, 1975; Jakobsson et al., 2010) or Antarctic ice shelves which would effect $\Delta \delta^{18} \mathrm{O}$ but not sea level, (2) a change in the $\delta^{18} \mathrm{O}$ of glacial ice (Pekar and DeConto, 2006; Winnick and Caves, 2015), (3) salinity (Rohling and Bigg, 1998) and/or (4) ocean circulation.

Global climate and ice-sheet models (DeConto et al., 2008) suggest that climatic conditions during much of the Miocene may have been conducive to bipolar glaciation, which would be required if the low sea levels inferred here were the result of enhanced global ice volume. While seismic imaging and drilling confirm that Antarctic ice sheets were established by the late Miocene (Anderson and Shipp, 2001) and ice volume estimates suggest the East Antarctic Ice Sheet periodically grew larger (25\%) than present (Pekar and DeConto, 2006) during the mid Miocene, it is hard to envision how an additional $50 \mathrm{~m}$ (sea level equivalent vertical meters) or more of ice could be added on top of the present-day volume of ice on Antarctica. 
Evidence of late Miocene glaciation of the Northern Hemisphere is sparser, possibly owing to poor preservation. However, ice-rafted debris deposits in marine sediment cores of Miocene age are recognized in the Arctic ( $<16 \mathrm{Ma})$, Fram Strait ( $<18 \mathrm{Ma})$, Greenland $(<7 \mathrm{Ma})$, Norwegian Sea ( $<11 \mathrm{Ma})$, Iceland Sea ( $<7.5 \mathrm{Ma})$, Baffin Bay $(<9 \mathrm{Ma})$ and North Pacific ( $<6.6 \mathrm{Ma}$ ) (De Schepper et al., 2014) indicating the presence of Northern Hemisphere ice by the late Miocene. Likewise, synthesis of late Miocene $\delta^{18} \mathrm{O}$ data from planktonic foraminifera by Williams et al. (2005) suggest significantly cooler than modern sea surface temperatures may have occurred at this time. Colder temperatures would also be consistent with the occurrence of bi-polar glaciations; however, uncertainties in ice-sheet thickness preclude a straightforward estimation of the Northern v. Southern Hemispheric contribution to the late Miocene sea-level lowstands we infer at Enewetak.

Moving into the Pliocene, our best-fit relative sea-level reconstruction (Fig. 3b), suggests that sea level, and consequently Enewetak's reefs, rose rapidly between 4-5 Ma with maximum highstand sea level exceeding modern during most of the Pliocene. Rapid reef accretion (>50 m) around $5 \mathrm{Ma}$ is also observed in well-dated stratigraphic sections from uplifted atolls in the Pacific (e.g., Kita-Diato-Jima-Ohde and Elderfield, 1992; Niue-Aharon et al., 1993), providing further evidence that a period of sustained low sea level during the late Miocene may have produced the accommodation depth necessary for the

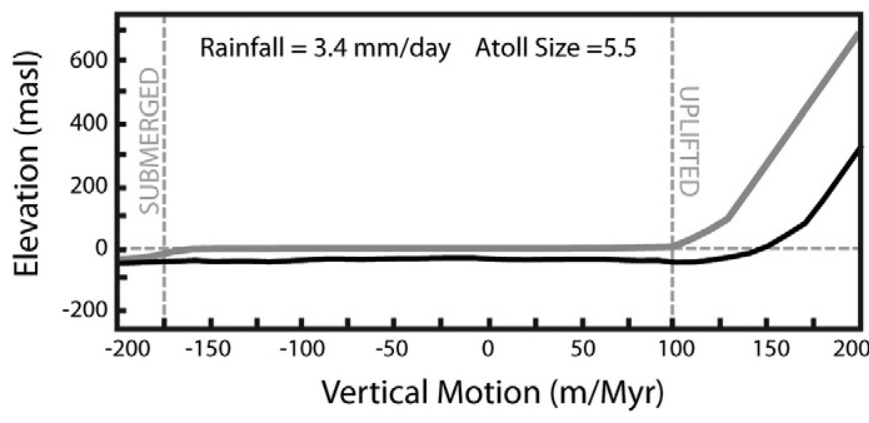

Fig. 6. Sensitivity of lagoon and rim final elevations to variable vertical motion rates. Rim and lagoon elevations are given by gray and black lines, respectively. Rainfall was held constant for these model runs.

observed reef growth during the ensuing early Pliocene transgression. Perhaps release of $\mathrm{CO}_{2}$ during this rapid buildup of coral reefs $\left(\mathrm{Ca}^{2+}+2 \mathrm{HCO}_{3}^{-} \rightarrow \mathrm{CaCO}_{3}+\mathrm{CO}_{2}+\mathrm{H}_{2} \mathrm{O}\right)$ may have contributed to observed shoaling of the carbonate compensation depth during the late Miocene and early Pliocene (Pälike et al., 2012).

Moving into the mid-late Pliocene, the model suggests an escalation of glacial-interglacial sea-level variability. Modeled lowstands around

\section{Subsidence Control}
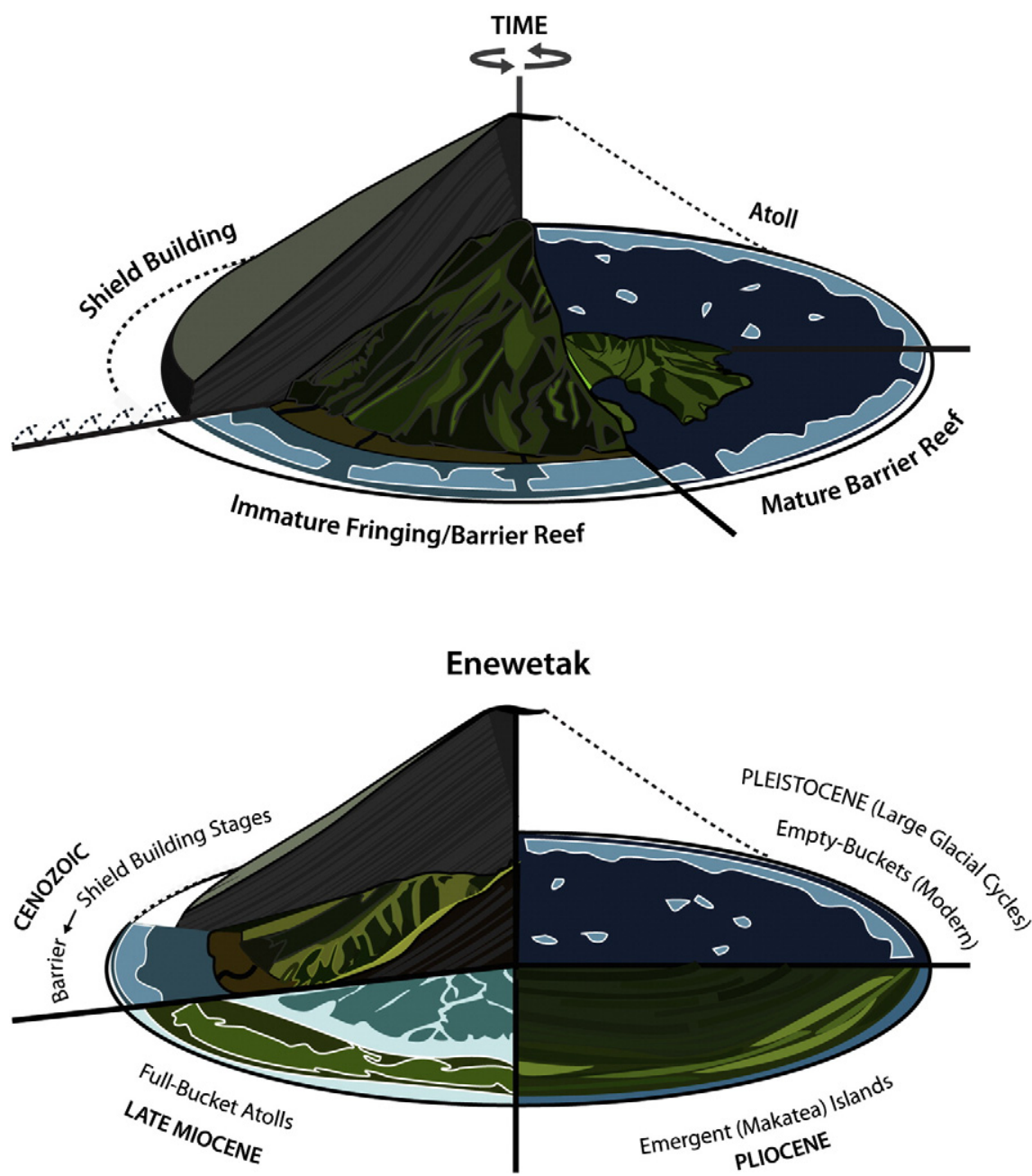

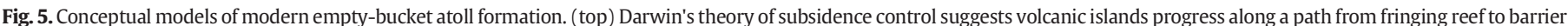

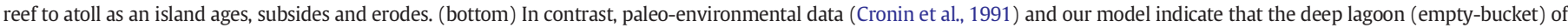

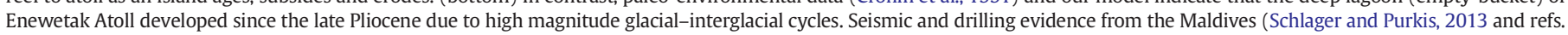

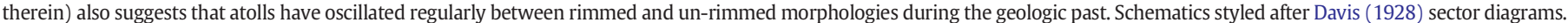


3.3, 3.6, 4.0 and 4.9 Ma correspond closely with widespread observational evidence (e.g., ice-rafted debris) of Northern Hemisphere ice expansion during the Pliocene (De Schepper et al., 2014). Similarly, dissolution through most of Enewetak's accumulated late Pliocene section, indicated by a subaerial exposure horizon separating unconforming mid-late Pliocene (>2.5 Ma) and mid Pleistocene (1.6 Ma) carbonates, is consistent with dissolution during expansion of large-scale Northern Hemisphere ice sheets after 2.7 Ma (Bailey et al., 2010). Net erosion of almost $50 \mathrm{~m}$ of lagoon sediment occurs in our synthetic stratigraphy between 3.1 and $1.5 \mathrm{Ma}$ (Fig. 3a). Our best-fit model suggests that this lagoon deepening requires sediments to dissolve at rates considerably faster than reef framework on the rim (Lagoon $F_{d l}=10.4 \times 10^{-5}$; Rim $F_{d r}=7.5 \times 10^{-5}$ ), compensating for the lagoon being exposed less frequently than the atoll rim.

\subsection{Atoll morphology}

Model results suggest the intensification of glacial-interglacial sealevel cycles during the Pleistocene drove a change in Enewetak's morphology from a Pliocene full-bucket to the empty-bucket morphology we see today, consistent with paleoenvironmental reconstructions from Enewetak, which show the dominance of ostracod lagoon species such as Loxoconcha and Hermanites during the Quaternary (Cronin et al., 1991). Over the past $8.5 \mathrm{Ma}$, model and ostracod data (Cronin et al., 1991) suggest that Enewetak, and by extension most large atolls, have oscillated between empty and full-bucket morphology, with a deep lagoon present throughout the Pleistocene and also around the Miocene/Pliocene transition (Figs. 3, 5). Together, the paleo-environmental data and model results suggests that differential dissolution and constructional rim growth through large-amplitude late Pliocene to early Pleistocene glacial sea-level cycles created the empty-bucket morphology we see today at Enewetak (Figs. 3, 5).

Bathymetric soundings from atoll lagoons in the western Pacific Ocean suggest that the modern empty-bucket morphology of atoll lagoons is also strongly influenced by sedimentation and island geometry. For instance, small atolls (Fig. 4), even in areas of high rainfall, have relatively shallow lagoons due to rapid infilling from the atoll rim during sea-level highstands. With increasing island size, the relative contribution of rim-derived sediment decreases, resulting in deeper lagoons. However, deeper lagoons are also less frequently exposed over a typical glacial-interglacial cycle, limiting the time-averaged dissolution rate and therefore preventing further lagoon deepening. The balance of these two effects-deeper lagoons with larger atoll size but also slower effective dissolution-restricts average lagoon depth to less than $\sim 50 \mathrm{~m}$. Our model is able to capture this interaction of island size with dissolution rate and, using our best-fit sea-level curve, closely matches observations of mean lagoon depth from 14 atolls across the Marshall Islands (Pearson's $\mathrm{r}=0.84, \mathrm{p}<0.01, \mathrm{n}=14$ ) (Fig. 4a).

Subsidence rate has a minor impact on modern lagoon relief. For example, simulations for an island with the same size and mean rainfall as Enewetak but subsidence rates between 0 and $100 \mathrm{~m} / \mathrm{Myr}$ ( $\sim 5$ times estimates in Section 3.1), produce a relatively narrow range of modern lagoon depths (30.4-37 mbsl). More substantial relief (Fig. 6) is generated only with very fast uplift (vertical motion (VM) $>100 \mathrm{~m} / \mathrm{Myr}$ ), positioning the island well above sea level or when rapid subsidence (VM $<-175 \mathrm{~m} / \mathrm{Myr}$ ) causes rim submergence during deglacial transgressions.

\section{Conclusions}

Altogether, our results show a considerably different pattern of sealevel variability over the past 8.5 Ma than implied by deep-sea oxygen isotope records, suggesting persistent bipolar glaciation and low sea level during the late Miocene, super-interglacials and higher sea level during the Pliocene, and intensification of glacial-interglacial oscillations during the Pleistocene. The widespread occurrence of modern empty-bucket atolls bears the imprint of these large-scale sea-level cycles. Using a simple numerical model we show that geographic changes in rainfall (dissolution) and island geometry (sedimentation) best explain the variability of atoll morphology in the modern Pacific.

\section{Acknowledgments}

Support for this work was provided through a Jackson School Distinguished Postdoctoral Fellowship to Michael Toomey. We appreciated the helpful feedback on an earlier version of this manuscript from Tom Cronin and Bruce Wardlaw as well as thoughtful reviews by Sam Purkis and an anonymous reviewer. Any use of trade, firm, or product names is for descriptive purposes only and does not imply endorsement by the U.S. Government.

\section{References}

Adams, C., Benson, R.H., Kidd, R., Ryan, W., Wright, R., 1977. The Messinian salinity crisis and evidence of late Miocene eustatic changes in the world ocean. Nature 269, 383-386.

Aharon, P., Goldstein, S.L., Wheeler, C.W., Jacobson, G., 1993. Sea-level events in the South Pacific linked with the Messinian salinity crisis. Geology 21, 771-775.

Anderson, J.B., Shipp, S.S., 2001. Evolution of the West Antarctic ice sheet. In: Alley, R.B., Bindschadler, R.A. (Eds.), The West Antarctic Ice Sheet: Behavior and EnvironmentAntarctic Research Series vol. 77. American Geophysical Union, Washington D.C., pp. 45-57.

Andréfouët, S., Muller-Karger, F.E., Robinson, J.A., Kranenburg, C.J., Torres-Pulliza, D. Spraggins, S.A., Murch, B., 2006. Global assessment of modern coral reef extent and diversity for regional science and management applications: a view from space. Proceedings of the 10th International Coral Reef Symposium. ICRS, Okinawa, Japan, pp. $1732-1745$.

Anthony, S.S., Peterson, F.L., MacKenzie, F.T., Hamlin, S.N., 1989. Geohydrology of the Laura fresh-water lens, Majuro atoll: a hydrogeochemical approach. Geol. Soc. Am. Bull. 101, 1066-1075.

Bailey, I., Bolton, C.T., DeConto, R.M., Pollard, D., Schiebel, R., Wilson, P.A., 2010. A low threshold for North Atlantic ice rafting from "low-slung slippery" late Pliocene ice sheets. Paleoceanography 25, PA1212.

Betzler, C., Lindhorst, S., Lüdmann, T., Weiss, B., Wunsch, M., Braga, J.C., 2015. The leaking bucket of a Maldives atoll: implications for the understanding of carbonate platform drowning. Mar. Geol. 366, 16-33.

Billups, K., Schrag, D., 2002. Paleotemperatures and ice volume of the past $27 \mathrm{Myr}$ revisited with paired $\mathrm{Mg} / \mathrm{Ca}$ and ${ }^{18} \mathrm{O} /{ }^{16} \mathrm{O}$ measurements on benthic foraminifera. Paleoceanography 17.

Bosence, D., Waltham, D., 1990. Computer modeling the internal architecture of carbonate platforms. Geology 18, 26-30.

Bosscher, H., Meesters, E.H., 1992. Depth related changes in the growth rate of Montastrea annularis. Proceedings of the 7th International Coral Reef Symposium. ICRS, Guam, pp. 507-512.

Bosscher, H., Schlager, W., 1992. Computer simulation of reef growth. Sedimentology 39, 503-512.

Braconnot, P., Otto-Bliesner, B., Harrison, S., Joussaume, S., Peterchmitt, J.-Y., Abe-Ouchi, A., Crucifix, M., Driesschaert, E., Fichefet, T., Hewitt, C., 2007. Results of PMIP2 coupled simulations of the mid-Holocene and last glacial maximum-part 1: experiments and large-scale features. Clim. Past 3, 261-277.

Broecker, W.S., 1975. Floating glacial ice caps in the Arctic Ocean. Science 188, 1116-1118.

Buigues, D., 1985. Principal facies and their distribution at Mururoa Atoll. Proceedings of the Fifth International Coral Reef Congress. ICRS, Tahiti, pp. 249-255.

Bybell, L.M., Poore, R.Z., 1991. Calcareous nannofossils and planktic foraminifers from Enewetak Atoll, western Pacific Ocean: Geologic and geophysical investigations of Enewetak Atoll. Republic of the Marshall Islands. U.S. Geological Survey Professional Paper 1513-C. U.S. Government Printing Office, Washington D.C.

Camoin, G., Ebren, P., Eisenhauer, A., Bard, E., Faure, G., 2001. A 300 000-yr coral reef record of sea level changes, Mururoa atoll (Tuamotu archipelago, French Polynesia). Palaeogeogr. Palaeoclimatol. Palaeoecol. 175, 325-341.

Chappell, J., 1980. Coral morphology, diversity and reef growth. Nature 286, 249-252.

Chib, S., Greenberg, E., 1995. Understanding the Metropolis-Hastings algorithm. Am. Stat. 49, 327-335.

Christiansen, S., 1964. On Lake Tegano, Rennell Island and some remarks on the problem of Rennell's origin. Geogr. Tidsskr. 63, 99-111.

Cleveland, W.S., 1979. Robust locally weighted regression and smoothing scatterplots J. Am. Stat. Assoc. 74, 829-836.

Couch, R.F., Fetzer, J.A., Goter, E.R., Ristvet, B.L., Tremba, E.L., Walter, D.R., Wendland, V.P. 1975. Drilling operations of Eniwetok Atoll during Project EXPOE. Air Force Weapons Laboratory Technical Report AFWL-TR-75-216.

Cronin, T.M., Brouwers, E.M., Bybell, L.M., Edwards, L.E., Gibson, T.G., Margerum, R., Poore, R., 1986. Pacific Enewetak Atoll Crater Exploration (PEACE) Program Enewetak Atoll, Republic of the Marshall Islands: part 2: paleontology and biostratigraphy of Enewetak Atoll. Marshall Islands: Application to OAK and KOA Craters. U.S. Geological Survey Open-File Report, pp. 86-159. 
Cronin, T.M., Bybell, L.M., Brouwers, E.M., Gibson, T.G., Margerum, R., Poore, R.Z., 1991. Neogene biostratigraphy and paleoenvironments of Enewetak Atoll, equatorial Pacific Ocean. Mar. Micropaleontol. 18, 101-114.

Daly, R.A., 1910. Pleistocene glaciation and the coral reef problem. Am. J. Sci. 30, 297-308 (Series 4).

Darwin, C., 1842. The structure and distribution of coral reefs: being the first part of the geology of the voyage of the Beagle, under the command of Capt. Fitzroy, RN During the Years 1832 to 1836. Smith, Elder and Company, London.

Davis, W.M., 1928. The Coral Reef Problem. American Geographical Society, New York.

De Schepper, S., Gibbard, P.L., Salzmann, U., Ehlers, J., 2014. A global synthesis of the marine and terrestrial evidence for glaciation during the Pliocene epoch. Earth Sci. Rev. $135,83-102$.

DeConto, R.M., Pollard, D., Wilson, P.A., Pälike, H., Lear, C.H., Pagani, M., 2008. Thresholds for Cenozoic bipolar glaciation. Nature 455, 652-656.

Detrick, R.S., Crough, S.T., 1978. Island subsidence, hot spots, and lithospheric thinning. J. Geophys. Res. 83, 1236-1244.

Dickinson, W.R., 2004. Impacts of eustasy and hydro-isostasy on the evolution and landforms of Pacific atolls. Palaeogeogr. Palaeoclimatol. Palaeoecol. 213, 251-269.

DiNezio, P.N., Tierney, J.E., 2013. The effect of sea level on glacial Indo-Pacific climate. Nat. Geosci. 6, 485-491.

Eberli, G.P., 2013. The uncertainties involved in extracting amplitude and frequency of orbitally driven sea-level fluctuations from shallow-water carbonate cycles. Sedimentology 60, 64-84.

Fairbanks, R.G., 1989. A 17,000-year glacio-eustatic sea level record: influence of glacial melting rates on the Younger Dryas event and deep-ocean circulation. Nature 342, 637-642.

Flesche Kleiven, H., Jansen, E., Fronval, T., Smith, T., 2002. Intensification of Northern Hemisphere glaciations in the circum Atlantic region (3.5-2.4 Ma)-ice-rafted detritus evidence. Palaeogeogr. Palaeoclimatol. Palaeoecol. 184, 213-223.

Folger, D.W., 1986. Sea-floor observations and subbottom seismic characteristics of OAK and KOA Craters, Enewetak Atoll, Marshall Islands. U.S. Geological Survey Bulletin. U.S. Government Printing Office (1678)

Gordon, C., Cooper, C., Senior, C.A., Banks, H., Gregory, J.M., Johns, T.C., Mitchell, J.F., Wood, R.A., 2000. The simulation of SST, sea ice extents and ocean heat transports in a version of the Hadley Centre coupled model without flux adjustments. Clim. Dyn. $16,147-168$.

Henry, T.W., Wardlaw, B.R., 1987. Pacific Enewetak Atoll Crater Exploration (PEACE) Program, Enewetak Atoll. Republic of the Marshall Islands. Part 3Stratigraphic Analysis and Other Geologic and Geophysical Studies in Vicinity of KOA and OAK Craters. U.S. Geological Survey Open-File Report, pp. 86-555.

Henry, T.W., Wardlaw, B.R., 1990. Introduction; Enewetak Atoll and the PEACE program. U.S. Geological Survey Professional Paper 1513-A. U.S. Government Printing Office, Washington, D.C.

Henry, T.W., Wardlaw, B.R., Skipp, B., Major, R.P., Tracey, J.I., 1986. Drilling operations and descriptions of boreholes in vicinity of KOA and OAK craters. U.S. Geological Survey Open-File Report (86-419).

Jakobsson, M., Nilsson, J., O'Regan, M., Backman, J., Löwemark, L., Dowdeswell, J.A., Mayer, L., Polyak, L., Colleoni, F., Anderson, L.G., 2010. An Arctic Ocean ice shelf during MIS 6 constrained by new geophysical and geological data. Quat. Sci. Rev. 29, 3505-3517.

Keating, B., 1992. Insular geology of the Line Islands. In: Keating, B., Bolton, B.R. (Eds.), Geology and Offshore Mineral Resources of the Central Pacific Basin. Springer-Verlag, New York, pp. 77-99.

Koelling, M., Webster, J.M., Camoin, G., Iryu, Y., Bard, E., Seard, C., 2009. SEALEX, an internal reef chronology and virtual drill logs from a spreadsheet-based reef growth model. Glob. Planet. Chang. 66, 149-159.

Kopp, R.E., Simons, F.J., Mitrovica, J.X., Maloof, A.C., Oppenheimer, M., 2013. A probabilistic assessment of sea level variations within the last interglacial stage. Geophys. J. Int. 193, 711-716.

Kulp, J.L., 1963. Potassium-argon dating of volcanic rocks. Bull. Volcanol. 26, 247-258.

Ladd, H.S., Schlanger, S.O., 1960. Bikini and nearby atolls, Marshall Islands; drilling operations on Eniwetok Atoll. U.S. Geological Survey Professional Paper 260-Y. U.S. Government Printing Office, Washington, D.C.

Ladd, H., Tracey, J., 1949. The problem of coral reefs. Sci. Mon. 69, 297-305.

Ladd, H.S., Ingerson, E., Russel, M., Stephenson, H.K., Townsend, R.C., 1953. Drilling on Eniwetok Atoll, Marshall Islands. Am. Assoc. Pet. Geol. Bull. 37, 2257-2280.

Ladd, H.S., Tracey, J.I., Gross, M.G., 1970. Deep drilling on Midway Atoll. U.S. Geological Survey Professional Paper 680-A. U.S. Government Printing Office, Washington D.C.

Lal, D., Gallup, C.D., Somayajulu, B.L., Vacher, L., Caffee, M.W., Jull, A.J., Finkel, R.C., Speed, R.C., Winter, A., 2005. Records of cosmogenic radionuclides $10 \mathrm{Be}, 26 \mathrm{Al}$ and $36 \mathrm{Cl}$ in corals: first studies on coral erosion rates and potential of dating very old corals. Geochim. Cosmochim. Acta 69, 5717-5728.

LaRiviere, J.P., Ravelo, A.C., Crimmins, A., Dekens, P.S., Ford, H.L., Lyle, M., Wara, M.W. 2012. Late Miocene decoupling of oceanic warmth and atmospheric carbon dioxide forcing. Nature 486, 97-100.

Larson, R., Erba, E., Nakanishi, M., Bergersen, D., Lincoln, J., 1995. Stratigraphic, vertica subsidence, and paleolatitude histories of Leg 144 guyots. Proc. Ocean Drill. Program Sci. Results. Ocean Drill. Program 915-933.

Lear, C.H., Rosenthal, Y., Wright, J.D., 2003. The closing of a seaway: ocean water masses and global climate change. Earth Planet. Sci. Lett. 210, 425-436.

Li, X., Kind, R., Yuan, X., Wölbern, I., Hanka, W., 2004. Rejuvenation of the lithosphere by the Hawaiian plume. Nature 427, 827-829.

Lincoln, J., Schlanger, S., 1987. Miocene sea-level falls related to the geologic history of Midway Atoll. Geology 15, 454-457.

Lincoln, J.M., Schlanger, S.O., 1991. Atoll stratigraphy as a record of sea level change: problems and prospects. J. Geophys. Res. Solid Earth 96, 6727-6752.
Lisiecki, L.E., Raymo, M.E., 2005. A Pliocene-Pleistocene stack of 57 globally distributed benthic 180 records. Paleoceanography 20, PA1003.

Ludwig, K., Halley, R., Simmons, K., Peterman, Z., 1988. Strontium-isotope stratigraphy of Enewetak Atoll. Geology 16, 173-177.

MacNeil, F.S., 1954. The shape of atolls; an inheritance from subaerial erosion forms. Am. J. Sci. 252, 402-427.

Metropolis, N., Rosenbluth, A.W., Rosenbluth, M.N., Teller, A.H., Teller, E., 1953. Equation of state calculations by fast computing machines. J. Chem.Phys. 21, 1087-1092.

Miller, K.G., Wright, J.D., Browning, J.V., Kulpecz, A., Kominz, M., Naish, T.R., Cramer, B.S., Rosenthal, Y., Peltier, W.R., Sosdian, S., 2012. High tide of the warm Pliocene: implications of global sea level for Antarctic deglaciation. Geology 40, 407-410.

Mitrovica, J., Milne, G., 2002. On the origin of late Holocene sea-level highstands within equatorial ocean basins. Quat. Sci. Rev. 21, 2179-2190.

Montaggioni, L.F., 2005. History of Indo-Pacific coral reef systems since the last glaciation: development patterns and controlling factors. Earth Sci. Rev. 71, 1-75.

Montaggioni, L.F., Camoin, G.F., 1997. Geology of Makatea Island, Tuamotu archipelago, French Polynesia. Geology and Hydrogeology of Carbonate IslandsDevelopments in Sedimentology 54. Elsevier, Amsterdam, pp. 453-474.

Montaggioni, L.F., Borgomano, J., Fournier, F., Granjeon, D., 2015. Quaternary atoll development: new insights from the two-dimensional stratigraphic forward modelling of Mururoa Island (Central Pacific Ocean). Sedimentology 62, 466-500.

Moucha, R., Forte, A.M., Mitrovica, J.X., Rowley, D.B., Quéré, S., Simmons, N.A., Grand, S.P., 2008. Dynamic topography and long-term sea-level variations: there is no such thing as a stable continental platform. Earth Planet. Sci. Lett. 271, 101-108.

Ohde, S., Elderfield, H., 1992. Strontium isotope stratigraphy of Kita-daito-jima Atoll, North Philippine Sea: implications for Neogene sea-level change and tectonic history. Earth Planet. Sci. Lett. 113, 473-486.

Pälike, H., Lyle, M.W., Nishi, H., Raffi, I., Ridgwell, A., Gamage, K., Klaus, A., Acton, G., Anderson, L., Backman, J., 2012. A Cenozoic record of the equatorial Pacific carbonate compensation depth. Nature 488, 609-614.

Parsons, B., Sclater, J.G., 1977. An analysis of the variation of ocean floor bathymetry and heat flow with age. J. Geophys. Res. 82, 803-827.

Paulay, G., McEdward, L.R., 1990. A simulation model of island reef morphology: the effects of sea level fluctuations, growth, subsidence and erosion. Coral Reefs 9, 51-62.

Pekar, S.F., DeConto, R.M., 2006. High-resolution ice-volume estimates for the early Miocene: evidence for a dynamic ice sheet in Antarctica. Palaeogeogr. Palaeoclimatol. Palaeoecol. 231, 101-109.

Purdy, E.G., Gischler, E., 2005. The transient nature of the empty bucket model of reef sedimentation. Sediment. Geol. 175, 35-47.

Purdy, E.G., Winterer, E.L., 2001. Origin of atoll lagoons. Geol. Soc. Am. Bull. 113, 837-854.

Purkis, S.J., Rowlands, G., Riegl, B., Renaud, P., 2010. The paradox of tropical karst morphology in the coral reefs of the arid Middle East. Geology 38, 227-230.

Quinn, T.M., 1991a. The history of post-Miocene sea level change: inferences from stratigraphic modeling of Enewetak Atoll. J. Geophys. Res. Solid Earth 96, 6713-6725.

Quinn, T.M., 1991b. Meteoric diagenesis of Plio-Pleistocene limestones at Enewetak Atoll. J. Sediment. Res. 61, 681-703.

Quinn, T.M., Lohmann, K., Halliday, A., 1991. Sr isotopic variation in shallow water carbonate sequences: stratigraphic, chronostratigraphic, and eustatic implications of the record at Enewetak Atoll. Paleoceanography 6, 371-385.

Raffi, I., Backman, J., Fornaciari, E., Pälike, H., Rio, D., Lourens, L., Hilgen, F., 2006. A review of calcareous nannofossil astrobiochronology encompassing the past 25 million years. Quat. Sci. Rev. 25, 3113-3137.

Robinson, J.A., Feldman, G.C., Kuring, N., Franz, B., Green, E., Noordeloos, M., Stumpf, R.P., 2000. Data fusion in coral reef mapping: working at multiple scales with SeaWiFS and astronaut photography. Proceedings of the 6th International Conference on Remote Sensing for Marine and Coastal Environments, pp. 473-483 (Charleston, South Carolina).

Rohling, E.J., Bigg, G.R., 1998. Paleosalinity and $\delta^{18} \mathrm{O}$ : a critical assessment. J. Geophys. Res. 103 (C1), 1307-1318

Sachs, J.P., Sachse, D., Smittenberg, R.H., Zhang, Z., Battisti, D.S., Golubic, S., 2009. Southward movement of the Pacific intertropical convergence zone AD 1400-1850. Nat. Geosci. 2, 519-525.

Schlager, W., Purkis, S.J., 2013. Bucket structure in carbonate accumulations of the Maldive, Chagos and Laccadive archipelagos. Int. J. Earth Sci. 102, 2225-2238.

Spencer, T., 1985. Rates of karst processes in raised reef limestones and their implications for coral reef histories. Proceedings of the Fifth International Coral Reef Congress, pp. 629-634 (Tahiti).

Stein, C.A., Stein, S., 1992. A model for the global variation in oceanic depth and heat flow with lithospheric age. Nature 359, 123-129.

Szabo, B., Tracey, J., Goter, E., 1985. Ages of subsurface stratigraphic intervals in the Quaternary of Enewetak Atoll, Marshall Islands. Quat. Res. 23, 54-61.

Toomey, M., Ashton, A.D., Perron, J.T., 2013. Profiles of ocean island coral reefs controlled by sea-level history and carbonate accumulation rates. Geology 41, 731-734.

Wardlaw, B.R., Quinn, T.M., 1991. The record of Pliocene sea-level change at Enewetak Atoll. Quat. Sci. Rev. 10, 247-258.

Warrlich, G.M.D., Waltham, D.A., Bosence, D.W.J., 2002. Quantifying the sequence stratigraphy and drowning mechanisms of atolls using a new 3-D forward stratigraphic modelling program (carbonate 3D). Basin Res. 14, 379-400.

Williams, M., Haywood, A.M., Taylor, S.P., Valdes, P.J., Sellwood, B.W., Hillenbrand, C.-D., 2005. Evaluating the efficacy of planktonic foraminifer calcite $\delta^{18} \mathrm{O}$ data for sea surface temperature reconstruction for the Late Miocene. Geobios 38, 843-863.

Winnick, M.J., Caves, J.K., 2015. Oxygen isotope mass-balance constraints on Pliocene sea level and East Antarctic ice sheet stability. Geology 43, 879-882.

Woodroffe, C., McLean, R., 1998. Pleistocene morphology and Holocene emergence of Christmas (Kiritimati) Island, Pacific Ocean. Coral Reefs 17, 235-248.

Zachos, J., Pagani, M., Sloan, L., Thomas, E., Billups, K., 2001. Trends, rhythms, and aberrations in global climate $65 \mathrm{Ma}$ to present. Science 292, 686-693. 